\title{
Influence of Yttrium on the Thermal Stability of Ti-Al-N Thin Films
}

\author{
Martin Moser ${ }^{1}$, Daniel Kiener ${ }^{2}$, Christina Scheu ${ }^{2}$, Paul H. Mayrhofer ${ }^{1, *}$ \\ 1 Department of Physical Metallurgy and Materials Testing, Montanuniversität Leoben, Franz Josef \\ Strasse 18,8700 Leoben, Austria; E-Mail: martin.moser@ruag.com (M.M) \\ 2 Department of Chemistry, Ludwig-Maximilians-University Munich, Butenandtstr. 5-13 (E), 81377 \\ Munich, Germany; E-Mails: daniel.kiener@unileoben.ac.at (D.K.); \\ christina.scheu@cup.uni-muenchen.de (C.S.)
}

* Author to whom correspondence should be addressed; E-Mail: paul.mayrhofer@unileoben.ac.at; Tel.: +43-3842-402-4211; Fax: +43-3842-402-4202.

Received: 5 January 2010; in revised form: 18 February 2010 / Accepted: 3 March 2010 /

Published: 4 March 2010

\begin{abstract}
Ti}_{1-\mathrm{x}} \mathrm{Al}_{\mathrm{x}} \mathrm{N}$ coated tools are commonly used in high-speed machining, where the cutting edge of an end-mill or insert is exposed to temperatures up to $1100{ }^{\circ} \mathrm{C}$. Here, we investigate the effect of Yttrium addition on the thermal stability of $\mathrm{Ti}_{1-\mathrm{x}} \mathrm{Al}_{\mathrm{x}} \mathrm{N}$ coatings. Reactive DC magnetron sputtering of powder metallurgically prepared $\mathrm{Ti}_{0.50} \mathrm{Al}_{0.50}$, $\mathrm{Ti}_{0.49} \mathrm{Al}_{0.49} \mathrm{Y}_{0.02}$, and $\mathrm{Ti}_{0.46} \mathrm{Al}_{0.46} \mathrm{Y}_{0.08}$ targets result in the formation of single-phase cubic (c) $\mathrm{Ti}_{0.45} \mathrm{Al}_{0.55} \mathrm{~N}$, binary cubic/wurtzite c/w-Ti $\mathrm{i}_{0.41} \mathrm{Al}_{0.57} \mathrm{Y}_{0.02} \mathrm{~N}$ and singe-phase w- $\mathrm{Ti}_{0.38} \mathrm{Al}_{0.54} \mathrm{Y}_{0.08} \mathrm{~N}$ coatings. Using pulsed $\mathrm{DC}$ reactive magnetron sputtering for the $\mathrm{Ti}_{0.49} \mathrm{Al}_{0.49} \mathrm{Y}_{0.02}$ target allows preparing single-phase c- $\mathrm{Ti}_{0.46} \mathrm{Al}_{0.52} \mathrm{Y}_{0.02} \mathrm{~N}$ coatings. By employing thermal analyses in combination with $\mathrm{X}$-ray diffraction and transmission electron microscopy investigations of as deposited and annealed (in He atmosphere) samples, we revealed that Y effectively retards the decomposition of the $\mathrm{Ti}_{1-\mathrm{x}-\mathrm{y}} \mathrm{Al}_{\mathrm{x}} \mathrm{Y}_{\mathrm{y}} \mathrm{N}$ solid-solution to higher temperatures and promotes the precipitation of c-TiN, c-YN, and w-AlN. Due to their different microstructure and morphology already in the as deposited state, the hardness of the coatings decreases from $\sim 35$ to $22 \mathrm{GPa}$ with increasing Y-content and increasing wurtzite phase fraction. Highest peak hardness of $\sim 38 \mathrm{GPa}$ is obtained for the Y-free c- $\mathrm{Ti}_{0.45} \mathrm{Al}_{0.55} \mathrm{~N}$ coating after annealing at $\mathrm{T}_{\mathrm{a}}=950{ }^{\circ} \mathrm{C}$, due to spinodal decomposition. After annealing above $1000{ }^{\circ} \mathrm{C}$ the highest hardness is obtained for the $2 \mathrm{~mol} \% \mathrm{YN}$ containing c- $\mathrm{Ti}_{0.46} \mathrm{Al}_{0.52} \mathrm{Y}_{0.02} \mathrm{~N}$ coating with $\sim 29$ and $28 \mathrm{GPa}$ for $\mathrm{T}_{\mathrm{a}}=1150$ and $1200{ }^{\circ} \mathrm{C}$, respectively.
\end{abstract}


Keywords: TiAlN; Yttrium; thermal stability; decomposition

\section{Introduction}

Owing to their excellent physical, chemical, and mechanical properties, $\operatorname{Ti}_{1-x} \mathrm{Al}_{\mathrm{x}} \mathrm{N}$ coatings are used in a broad field of applications, ranging from the protection of components in aerospace and the automotive industry to the utilization as hard and wear resistant overlays on e.g., tools, dies, and moulds [1-3]. In high-speed machining, where the cutting edge of an end-mill or insert is exposed to temperatures up to $1100{ }^{\circ} \mathrm{C}, \mathrm{Ti}_{1-\mathrm{x}} \mathrm{Al}_{\mathrm{x}} \mathrm{N}$ coated tools are commonly employed [4]. For these applications, the oxidation resistance, thermal stability and microstructure are crucial in influencing the tool life time and performance [5].

When grown by plasma-assisted vapor deposition techniques $\mathrm{Ti}_{1-\mathrm{x}} \mathrm{Al}_{\mathrm{x}} \mathrm{N}$ crystallizes in a supersaturated solid-solution cubic (c) $\mathrm{NaCl}$ structure up to AlN mole fractions $\mathrm{x} \sim 0.7$. This value strongly depends on the deposition-conditions used and the resulting defect-density, microstructure, and stress state of the coatings [6,7]. Hence, various maximum AlN fractions in single-phase c- $\mathrm{Ti}_{1}$ ${ }_{x} \mathrm{Al}_{\mathrm{x}} \mathrm{N}$ coatings are reported in the literature. Exceeding the metastable AlN solubility results in a mixed $(\mathrm{NaCl}+\mathrm{ZnS}$-wurtzite) structure, or the films crystallize completely in the $\mathrm{ZnS}$-wurtzite (w) modification [6-13]. As c- $\mathrm{Ti}_{1-\mathrm{x}} \mathrm{Al}_{\mathrm{x}} \mathrm{N}$ films with high $\mathrm{Al}$ contents have superior physical, mechanical, and chemical properties, and show better oxidation resistance than their two-phased or single-phased wurtzite counterparts, they are generally preferred for industrial applications.

The thermal stability and the microstructural evolution during thermal exposure of advanced hard coatings can be seen as key factors for their optimal performance when used on tools or components that are exposed to high temperatures. Therefore, the investigation of the thermal stability of such coatings is of high interest [14]. In recent years, combined thermal analyses were used to in situ derive reaction temperatures, energy inputs and associated mass changes through the formation of reaction products or volatile species $[11,15-18]$. The decomposition process of $\mathrm{Ti}_{1-\mathrm{x}} \mathrm{Al}_{\mathrm{x}} \mathrm{N}$ has been described in detail for AlN mole fractions $x$ ranging from 0.25 to 0.75 [2,9,11,13,16,19-22].

Further improvement of the coating properties and thermal stability can be realized by alloying with beneficial elements, e.g., reactive elements $[5,23]$. The element yttrium is used to improve oxidation resistance of structural and coating materials [24,25]. However, it is important to consider that especially metastable phases are sensitive to any chemical variation. Recently, we showed by ab initio calculations that the addition of 6.75 at $\% \mathrm{Y}$ to the metal sublattice of $\mathrm{Ti}_{1-\mathrm{x}} \mathrm{Al}_{\mathrm{x}} \mathrm{N}$ decreases the metastable solubility limit for $\mathrm{AlN}$ in cubic $\mathrm{Ti}_{1-\mathrm{x}} \mathrm{Al}_{\mathrm{x}} \mathrm{N}$ from $\mathrm{x}_{\mathrm{c}-\max } \sim 0.67$ to 0.50 [26]. The ab initioderived results were verified by experimental studies exhibiting a single-phase cubic structure for $\mathrm{Ti}_{0.45} \mathrm{Al}_{0.55} \mathrm{~N}$, a mixed cubic/wurtzite structure for $\mathrm{Ti}_{0.41} \mathrm{Al}_{0.57} \mathrm{Y}_{0.02} \mathrm{~N}$ and $\mathrm{Ti}_{0.43} \mathrm{Al}_{0.52} \mathrm{Y}_{0.05} \mathrm{~N}$, and a singlephase wurtzite structure for $\mathrm{Ti}_{0.38} \mathrm{Al}_{0.54} \mathrm{Y}_{0.08} \mathrm{~N}$. Due to the formation of a wurtzite phase in these Y-containing $\mathrm{Ti}_{1-\mathrm{x}} \mathrm{Al}_{\mathrm{x}} \mathrm{N}$ films their hardness is $\sim 22 \mathrm{GPa}$, much smaller than the $\sim 35 \mathrm{GPa}$ obtained for the Y-free $c-\mathrm{Ti}_{0.45} \mathrm{Al}_{0.55} \mathrm{~N}$ film [26]. By optimizing the deposition conditions when using the $\mathrm{Ti}_{0.49} \mathrm{Al}_{0.49} \mathrm{Y}_{0.02}$ target, coatings can be prepared exhibiting a single-phase cubic structure with a chemical composition of $\mathrm{c}-\mathrm{Ti}_{0.46} \mathrm{Al}_{0.52} \mathrm{Y}_{0.02} \mathrm{~N}$ and a hardness of $33 \mathrm{GPa}$ [27]. As described in [27], the 
optimized deposition conditions result in an increased energy transferred to the growing species as well as a changed chemical composition of the growing film towards lower Al contents. Hence, the coating composition shifts deeper into the metastable cubic phase field.

In the present study, we investigate the thermal decomposition process of $\operatorname{Ti}_{1-\mathrm{x}-\mathrm{y}} \mathrm{Al}_{\mathrm{x}} \mathrm{Y}_{\mathrm{y}} \mathrm{N}$ films having YN contents of 0,2 , and $8 \mathrm{~mol} \%$. We applied electron probe microanalyses, $\mathrm{X}$-ray diffraction (XRD), and transmission electron microscopy (TEM) for chemical and structural investigations of as deposited and annealed samples. The decomposition process itself is monitored by simultaneous thermal analyses (STA), combining differential scanning calorimetry (DSC), thermo-gravimetric analyses (TGA), and mass spectrometry (MS). These investigations allow for a correlation of hardness variations with microstructure and phase-composition variations as a function of the thermal treatment.

\section{Experimental Section}

$\mathrm{Ti}_{1-\mathrm{x}-\mathrm{y}} \mathrm{Al}_{\mathrm{x}} \mathrm{Y}_{\mathrm{y}} \mathrm{N}$ thin films were grown on $\mathrm{MgO}(100)$ and $\mathrm{Si}(100)$ substrates $\left(20 \times 7 \times 0.35 \mathrm{~mm}^{3}\right)$ and low-alloyed steel foils in a modified Leybold Z-400 facility by reactive unbalanced magnetron sputtering from a $\emptyset 76 \mathrm{~mm} \mathrm{Ti} \mathrm{i}_{0.50} \mathrm{Al}_{0.50}, \mathrm{Ti}_{0.49} \mathrm{Al}_{0.49} \mathrm{Y}_{0.02}$, and $\mathrm{Ti}_{0.46} \mathrm{Al}_{0.46} \mathrm{Y}_{0.08}$ compound target (powdermetallurgically prepared by PLANSEE GmbH, Lechbruck, Germany, 99.9\% purity) in a mixed Ar- $\mathrm{N}_{2}$ (both with $99.999 \%$ purity) glow discharge using a $\mathrm{N}_{2} /$ Ar partial pressure ratio of 0.4 and a working gas pressure of $0.5 \mathrm{~Pa}$. The substrate temperature of $550{ }^{\circ} \mathrm{C}$ and $\mathrm{DC}$ bias potential of $-50 \mathrm{~V}$ were kept constant for all deposition runs. The substrates were positioned $5 \mathrm{~cm}$ above the target race track (substrates are parallel aligned to the target surface) as schematically shown in [27]. An ENI RPG-50 asymmetric bi-polar pulsed power supply, set to provide $400 \mathrm{~W}$ in power regulation mode, was used for DC and for pulsed DC magnetron sputtering. The pulsing frequency of a $+37 \mathrm{~V}$ reverse voltage pulse was set to $80 \mathrm{kHz}$ and the positive pulse length $t_{\text {rev }}$ was kept constant at $4976 \mathrm{~ns}$ to guarantee a single-phase cubic growth of a $\mathrm{Ti}_{0.46} \mathrm{Al}_{0.52} \mathrm{Y}_{0.02} \mathrm{~N}$ film (i.e., with $2 \mathrm{~mol} \% \mathrm{YN}$ ), for more details see [27].

Simultaneous thermal analyses in the temperature range between 450 and $1500{ }^{\circ} \mathrm{C}$ were conducted using a Netzsch STA 409 instrument. The measurements were carried out with a heating rate of $20 \mathrm{~K} / \mathrm{min}$ in flowing He atmosphere (99.9\% purity, $20 \mathrm{sccm}$ flow rate). Post-deposition annealing to distinct temperatures $\mathrm{T}_{\mathrm{a}}$ was performed in He atmosphere using a heating rate of $20 \mathrm{~K} / \mathrm{min}$ immediately followed by a cooling step at a rate of $40 \mathrm{~K} / \mathrm{min}$.

The structure and phase identification of the thin films were investigated using a Siemens D500 $\mathrm{X}$-ray diffractometer with $\mathrm{Cu}-\mathrm{K} \alpha$ radiation in the $2 \theta$ range 30-65 deg in Bragg-Brentano geometry. For the classification of the obtained reflexes, the JCPDS database was used [29]. The $2 \theta$ positions of the solid-solution cubic and wurtzite $\mathrm{Ti}_{0.5} \mathrm{Al}_{0.5} \mathrm{~N}$ phases are derived from lattice constants obtained by ab initio calculation, see [26].

To avoid overlap with the substrate material contributions, thermal analyses and annealing experiments for XRD were performed on powdered film material after chemical removal from their low alloy steel substrates with $10 \mathrm{~mol} \%$ nitric acid. TEM plan view samples were also prepared from free-standing film material, which was subsequently ion-thinned to electron-microscopy transparency using a Gatan PIPS. TEM measurements were conducted on a Philips CM12 at $120 \mathrm{keV}$ to study the coating morphology in the as deposited state and after annealing. Furthermore, selected coatings were 
investigated by high resolution TEM (HRTEM) and high angle annular dark field (HAADF) imaging in scanning TEM mode using a FEI Titan $80-300 \mathrm{keV}$. This microscope is equipped with an energy dispersive X-ray detector from EDAX and a post-column energy filter (GIF Tridiem from Gatan) for analytical investigations, which were also performed at selected coatings. The Titan was operated either at $80 \mathrm{keV}$ or $300 \mathrm{keV}$.

During scanning electron microscopy (SEM) investigations with a Zeiss EVO 50 microscope, the average chemical composition of the films was determined by energy dispersive x-ray analysis (EDX) with an Oxford Instruments INCA EDX unit using metallic Al and Y and a TiN film standard. Quantification of the latter was obtained by Rutherford backscattering spectroscopy as described in [30].

The hardness $(\mathrm{H})$ of coatings deposited on $\mathrm{MgO}$ in their as deposited state and after annealing at different $\mathrm{T}_{\mathrm{a}}$ in He was measured by nano-indentation with a CSIRO ultra micro indentation system (UMIS) equipped with a Berkovich-indenter. With respect to a proper statistic at least 50 indents are performed for each sample with maximum loads ranging from 10 to $45 \mathrm{mN}$ keeping the indentation depth below $10 \%$ of the coating thickness, which was $\sim 3.0 \mu \mathrm{m}$ for all coatings investigated.

\section{Results and Discussion}

EDX analyses in the SEM yielded $\mathrm{N}$ contents of $51.0 \pm 0.5$ at $\%$ and $\mathrm{O}$ contents below the detection limit for the coatings investigated. The Y-free DC magnetron sputtered reference coating had an elemental composition in the metallic sub-lattice of $\mathrm{Ti}=45$ at $\%$ and $\mathrm{Al}=55$ at $\%$ and a single-phase cubic microstructure after deposition. This film will be referenced throughout the work as c- $\mathrm{Ti}_{0.45} \mathrm{Al}_{0.55} \mathrm{~N}$. Using the same standard conditions during DC sputtering, and equipping the magnetron with a $\mathrm{Ti}_{0.49} \mathrm{Al}_{0.49} \mathrm{Y}_{0.02}$ target, resulted in the formation of a binary phased cubic/wurtzite $\mathrm{c} / \mathrm{w}-\mathrm{Ti}_{0.41} \mathrm{Al}_{0.57} \mathrm{Y}_{0.02} \mathrm{~N}$ film [26]. By using a $\mathrm{Ti}_{0.46} \mathrm{Al}_{0.46} \mathrm{Y}_{0.08}$ target, coatings with a predominant wurtzite phase and an $\mathrm{AlN}$ and $\mathrm{YN}$ mole fraction of $\mathrm{x}=0.54$ and $\mathrm{y}=0.08$, respectively, are formed. Hence, these will be referred to as $\mathrm{w}-\mathrm{Ti}_{0.38} \mathrm{Al}_{0.54} \mathrm{Y}_{0.08} \mathrm{~N}$ [26]. When changing the deposition conditions for the $\mathrm{Ti}_{0.49} \mathrm{Al}_{0.49} \mathrm{Y}_{0.02}$ target from DC sputtering to bipolar pulsed sputtering with small frequencies and long positive pulse durations (see experimental section) the resulting $\mathrm{Ti}_{0.46} \mathrm{Al}_{0.52} \mathrm{Y}_{0.02} \mathrm{~N}$ coating exhibits a single-phase cubic structure, as described in [27]. Consequently, these films will be referred to as c- $\mathrm{Ti}_{0.46} \mathrm{Al}_{0.52} \mathrm{Y}_{0.02} \mathrm{~N}$. The biaxial stresses, obtained by a cantilever beam method [28] of coated $\mathrm{Si}$ (100) stripes, are $-1.98,-1.81,-0.31$, and $-0.81 \mathrm{GPa}$ for $\mathrm{c}-\mathrm{Ti}_{0.45} \mathrm{Al}_{0.55} \mathrm{~N},{ }^{\mathrm{c}}-\mathrm{Ti}_{0.46} \mathrm{Al}_{0.52} \mathrm{Y}_{0.02} \mathrm{~N}$, $\mathrm{c} / \mathrm{w}-\mathrm{Ti}_{0.41} \mathrm{Al}_{0.57} \mathrm{Y}_{0.02} \mathrm{~N}$, and $\mathrm{w}-\mathrm{Ti}_{0.38} \mathrm{Al}_{0.54} \mathrm{Y}_{0.08} \mathrm{~N}$, respectively.

\subsection{Simultaneous thermal analyses}

Dynamic annealing of powdered film material during DSC with $20 \mathrm{~K} / \mathrm{min}$ resulted in a broad exothermic feature in the temperature range of 500 and $900{ }^{\circ} \mathrm{C}$ for all coatings investigated (Figure 1a). For $\mathrm{T}_{\mathrm{a}} \geq 900{ }^{\circ} \mathrm{C}$, pronounced exothermal contributions were detected with peak temperatures increasing from $1052{ }^{\circ} \mathrm{C}$ for $\mathrm{c}-\mathrm{Ti}_{0.45} \mathrm{Al}_{0.55} \mathrm{~N}(0 \% \mathrm{YN})$ to $1118{ }^{\circ} \mathrm{C}$ for $\mathrm{c}-\mathrm{Ti}_{0.46} \mathrm{Al}_{0.52} \mathrm{Y}_{0.02} \mathrm{~N}$ ( $2 \% \mathrm{YN}$ ), to $1167{ }^{\circ} \mathrm{C}$ for $\mathrm{c} / \mathrm{w}-\mathrm{Ti}_{0.41} \mathrm{Al}_{0.57} \mathrm{Y}_{0.02} \mathrm{~N}(2 \% \mathrm{YN})$, and to $1197{ }^{\circ} \mathrm{C}$ for $\mathrm{w}-\mathrm{Ti}_{0.38} \mathrm{Al}_{0.54} \mathrm{Y}_{0.08} \mathrm{~N}$ $(8 \% \mathrm{YN})$. The TGA and MS measurements suggest a $\mathrm{N}_{2}$-release connected mass loss for $\mathrm{T}_{\mathrm{a}} \geq 1200{ }^{\circ} \mathrm{C}$ (Figure $1 \mathrm{~b}$ and $\mathrm{c}$ ). The total mass losses during this experiment are $\sim 3 \%$ for $\mathrm{Y}$-free $\mathrm{c}-\mathrm{Ti}_{1-\mathrm{x}} \mathrm{Al} \mathrm{x}_{\mathrm{x}} \mathrm{N}, \sim 2 \%$ 
for the $2 \%$ YN containing films $\left(\mathrm{c}-\mathrm{Ti}_{0.46} \mathrm{Al}_{0.52} \mathrm{Y}_{0.02} \mathrm{~N}\right.$ and $\left.\mathrm{c} / \mathrm{w}-\mathrm{Ti}_{0.41} \mathrm{Al}_{0.57} \mathrm{Y}_{0.02} \mathrm{~N}\right)$, and $4 \%$ for the $8 \%$ YN containing $\mathrm{w}-\mathrm{Ti}_{0.38} \mathrm{Al}_{0.54} \mathrm{Y}_{0.08} \mathrm{~N}$ coating, which correspond to 5.5, 3.8, 3.7 and 7.7 at \% $\mathrm{N}$, respectively. Although the EDX measurements performed in the SEM suggest our coatings are slightly over-stoichiometric with nitrogen contents of 51-52 at \%, the observed N-release is considerably higher than the 1-2 at \% over-stoichiometric nitrogen content. Nitrogen losses exceeding overstoichiometric content at temperatures between 1000 and $1150{ }^{\circ} \mathrm{C}$ for $\mathrm{Ti}_{0.5} \mathrm{Al}_{0.5} \mathrm{~N}, \mathrm{~V}_{0.5} \mathrm{Al}_{0.5} \mathrm{~N}$ and $\mathrm{Cr}_{0.5} \mathrm{Al}_{0.5} \mathrm{~N}$ grown in industrial sized sputter devices have also been reported in [31].

Figure 1. Simultaneous thermal analysis of $c-\mathrm{Ti}_{0.45} \mathrm{Al}_{0.55} \mathrm{~N} \quad\left(\begin{array}{llll}0 & \mathrm{~mol} & \% & \mathrm{YN}\end{array}\right)$, c- $\mathrm{Ti}_{0.46} \mathrm{Al}_{0.52} \mathrm{Y}_{0.02} \mathrm{~N}$ (2 mol \% YN), binary c/w- $\mathrm{Ti}_{0.41} \mathrm{Al}_{0.57} \mathrm{Y}_{0.02} \mathrm{~N}(2 \mathrm{~mol} \% \mathrm{YN})$, and singlephase $\mathrm{w}-\mathrm{Ti}_{0.38} \mathrm{Al}_{0.54} \mathrm{Y}_{0.08} \mathrm{~N}$ (8 mol \% YN) in He atmosphere up to $1400{ }^{\circ} \mathrm{C}$. (a) $\mathrm{DSC}$, (b) TGA, and (c) MS monitoring of $\mathrm{N}_{2}$.

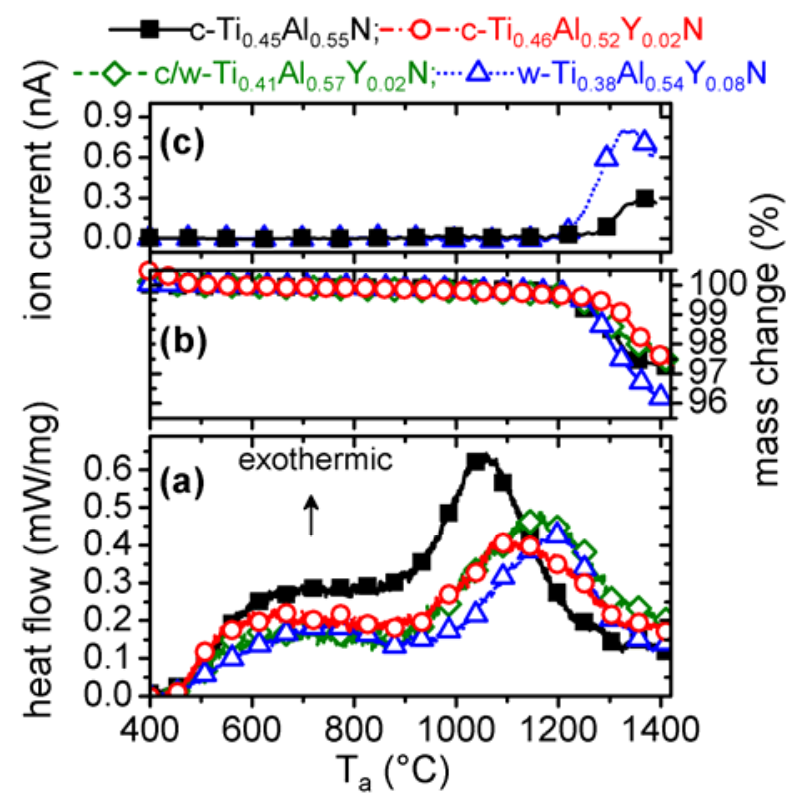

Interpretation of the individual DSC features during annealing of the coatings was conducted by structural and phase compositional investigations with XRD and plan-view TEM of free-standing coatings after annealing to various $\mathrm{T}_{\mathrm{a}}$.

\subsection{Structure and morphology}

\subsubsection{Single phase cubic $\mathrm{Ti}_{0.45} \mathrm{Al}_{0.55} \mathrm{~N}$}

XRD patterns of $\mathrm{c}-\mathrm{Ti}_{0.45} \mathrm{Al}_{0.55} \mathrm{~N}$ in the as deposited state and after annealing to $\mathrm{T}_{\mathrm{a}}$ are presented in Figure 2. The as deposited film has a single cubic phase with a lattice parameter $a$ of $\sim 4.178 \AA$ [26]. The XRD pattern obtained after annealing to 700 and $850{ }^{\circ} \mathrm{C}$ exhibit no major changes to the as deposited state with comparable $2 \theta$ positions, intensities, and widths of the XRD peaks. Therefore, the exothermic DSC feature in the temperature range $500-850{ }^{\circ} \mathrm{C}$ is attributed to recovery processes of deposition-induced defects, which generally result in stress relaxation as described in [9,11]. The XRD pattern of the $900{ }^{\circ} \mathrm{C}$ annealed coating reveals a decrease in peak intensities but an increase in peak 
broadening of the cubic $\mathrm{Ti}_{1-\mathrm{x}} \mathrm{Al}_{\mathrm{x}} \mathrm{N}$ reflexes. This indicates grain refinement and probably also an increase in microstresses due to spinodal decomposition [16,32].

Figure 2. XRD evolution of $\mathrm{c}-\mathrm{Ti}_{0.45} \mathrm{Al}_{0.55} \mathrm{~N}(0 \mathrm{~mol} \% \mathrm{YN})$ with annealing temperature $\mathrm{T}_{\mathrm{a}}$ up to $1500^{\circ} \mathrm{C}$.

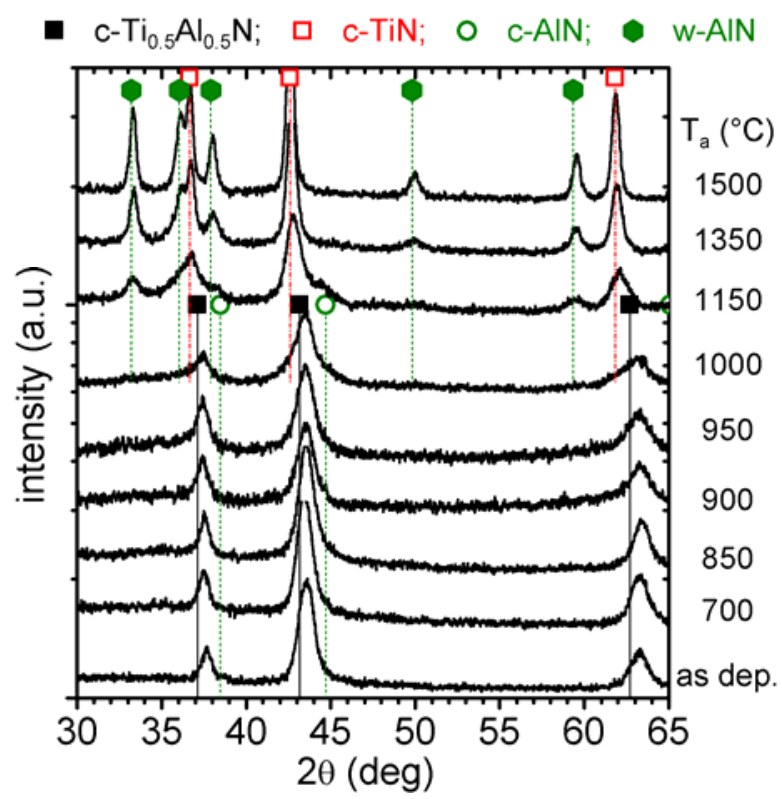

In the $\mathrm{Ti}_{1-\mathrm{x}} \mathrm{Al}_{\mathrm{x}} \mathrm{N}$ system a characteristic sign for spinodal decomposition is a shoulder formation on both sides - i.e., higher and lower diffraction angles — of the cubic matrix XRD reflections. This can especially be observed in the $2 \theta$ range $41-47 \mathrm{deg}$ (around the (200) reflex), since here the individual standard positions of c-TiN, c-AlN, and w-AlN do not interfere, see Figure 2. After annealing to $900{ }^{\circ} \mathrm{C}$, the XRD patterns exhibit these shoulders on both sides of the cubic reflexes and hence they provide a clear evidence for spinodal decomposition of the cubic $\operatorname{Ti}_{0.45} \mathrm{Al}_{0.55} \mathrm{~N}$ solid-solution, as proven by various calculations and experiments [6,11,16,32]. A broad x-ray diffraction response in the $2 \theta$ range 32-36 deg indicates the formation of the wurtzite phases.

When the coating is further annealed, the cubic solid-solution matrix XRD reflexes decrease in intensity and shift to lower $2 \theta$ diffraction angles (which can especially be seen for the peak at $\sim 63 \mathrm{deg}$ ) for temperatures $>950{ }^{\circ} \mathrm{C}$. Simultaneously, the shoulders on both sides of the cubic matrix peak, indicating the formation of cubic Al- and Ti-rich domains, become more pronounced. The XRD pattern of the coatings after annealing at $1000{ }^{\circ} \mathrm{C}$ clearly shows this shoulder formation, i.e., the spinodal decomposition.

After annealing the coating to $1150{ }^{\circ} \mathrm{C}$, strong reflexes for c-TiN and w-AlN can be detected by XRD at the expense of the cubic solid-solution matrix. In addition, the XRD pattern exhibits evidence for remaining c-AlN phases at this annealing stage. The XRD pattern of the 1350 and $1500{ }^{\circ} \mathrm{C}$ annealed samples reveal a fully decomposed microstructure, where the individual peaks fit to c-TiN and w-AlN, only traces of c-AlN can be detected. In addition, the XRD peaks sharpened, indicating the growth of the recrystallized grains and change in texture. 
The morphological changes in $c-\mathrm{Ti}_{0.45} \mathrm{Al}_{0.55} \mathrm{~N}$ due to the annealing treatment and the observed structural changes were investigated by TEM, see Figure 3. The as deposited film (Figure 3a) has a dense columnar microstructure (as proven by earlier studies, see [26,27]) with relatively large column diameters of $\sim 100 \mathrm{~nm}$, and the corresponding selected area electron diffraction pattern (SAED, inset in Figure 3a) confirms the single-phase cubic structure observed by XRD. TEM investigations of the coating after annealing to $900{ }^{\circ} \mathrm{C}$, Figure $3 \mathrm{~b}$, suggest an average grain size of $\sim 30 \mathrm{~nm}$. In a recent investigation on the thermal decomposition of $\mathrm{Ti}_{1-\mathrm{x}} \mathrm{Al}_{\mathrm{x}} \mathrm{N}$ by atom probe tomography, clustering of Al-rich and Al-depleted $\mathrm{Ti}_{1-\mathrm{x}} \mathrm{Al}_{\mathrm{x}} \mathrm{N}$ solid-solution areas within the $\mathrm{c}-\mathrm{Ti}_{1-\mathrm{x}} \mathrm{Al}_{\mathrm{x}} \mathrm{N}$ matrix grains was observed after annealing to $900{ }^{\circ} \mathrm{C}$ [19]. In addition to these results, we showed that the spinodal decomposition to form alternating Al- and Ti-rich domains can also be connected with the formation of an incoherent, wurtzite AlN-rich phase at the grain boundary.

Figure 3. Plan view TEM micrographs of $\mathrm{c}-\mathrm{Ti}_{0.45} \mathrm{Al}_{0.55} \mathrm{~N}$ in the (a) as deposited state and after annealing to (b) $900{ }^{\circ} \mathrm{C}$, (c) $1050{ }^{\circ} \mathrm{C}$, and (d) $1350{ }^{\circ} \mathrm{C}$. The small insets in (a) and (b) show their corresponding SAED patterns.

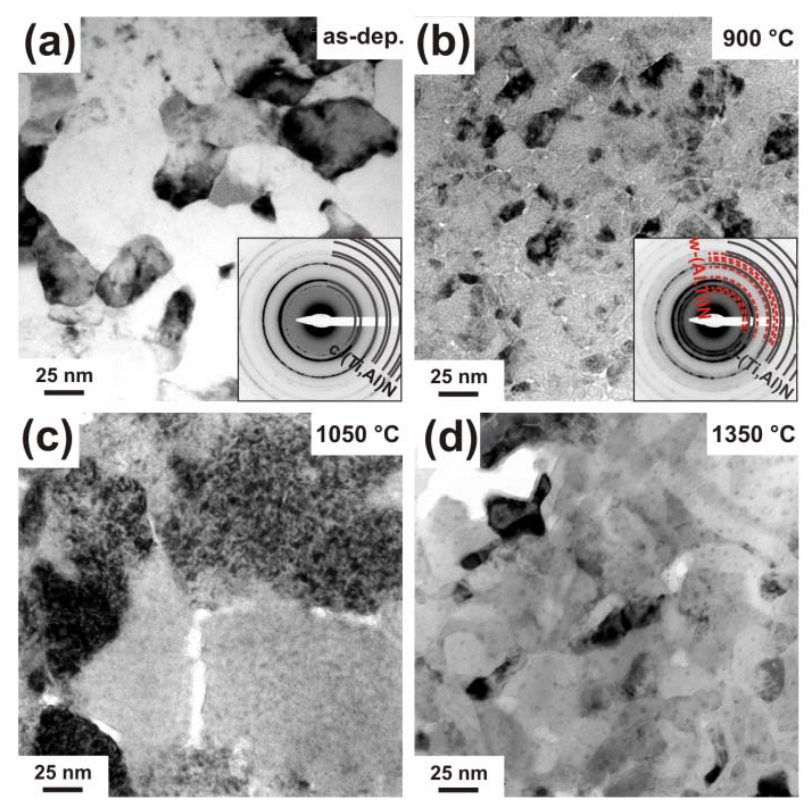

The TEM investigation of a sample annealed to $1050{ }^{\circ} \mathrm{C}$ (Figure $3 \mathrm{c}$ ) reveals a microstructure composed of domains with $\sim 150 \mathrm{~nm}$ in diameter and a grain boundary phase with $>10 \mathrm{~nm}$ in thickness. The recrystallized coating structure after annealing at $1350{ }^{\circ} \mathrm{C}$ is shown in the TEM plan-view micrograph in Figure 3d. The image exhibits an interlinked network of $>100 \mathrm{~nm}$ sized elongated, vermicular shaped grains and $<10 \mathrm{~nm}$ sized precipitates within the domains. Such interconnected microstructures are typical for spinodally decomposed materials and are described in literature theoretically and experimentally [33-35]. A corresponding interlinked three-dimensional network has recently been presented by atom probe investigations of $1350{ }^{\circ} \mathrm{C}$ annealed $\mathrm{Ti}_{1-\mathrm{x}} \mathrm{Al} \mathrm{x}_{\mathrm{x}} \mathrm{N}$ [19]. The decrease in grain size from the $1050{ }^{\circ} \mathrm{C}$ annealed sample to the $1350{ }^{\circ} \mathrm{C}$ annealed sample is due to the formation of new phases, compare Figure 2.

Detailed plan-view TEM investigations of the $1050{ }^{\circ} \mathrm{C}$ annealed coatings are presented in overfocus condition in Figure 4. Along with the large grains, which hint a still existing columnar 
microstructure, the grain boundary phase is visible, see the area labeled with (1) in Figure 4. Also, precipitates with average sizes of $\sim 7 \mathrm{~nm}$ diameter within the large domains can be identified, see e.g., the areas labelled with (2) in Figure 4. Domain sizes around $6 \mathrm{~nm}$ in diameter of $1050{ }^{\circ} \mathrm{C}$ annealed $\mathrm{Ti}_{0.5} \mathrm{Al}_{0.5} \mathrm{~N}$ coatings were also detected by small angle neutron scattering [16].

Figure 4. Over-focused plan view TEM micrograph of $c-\mathrm{Ti}_{0.45} \mathrm{Al}_{0.55} \mathrm{~N}$ after annealing to $1050{ }^{\circ} \mathrm{C}$ taken at a lower magnification than in Figure 3 . The grain boundary phase is indexed with (1) and the formation of nm-size precipitates within the grains are indexed with (2).

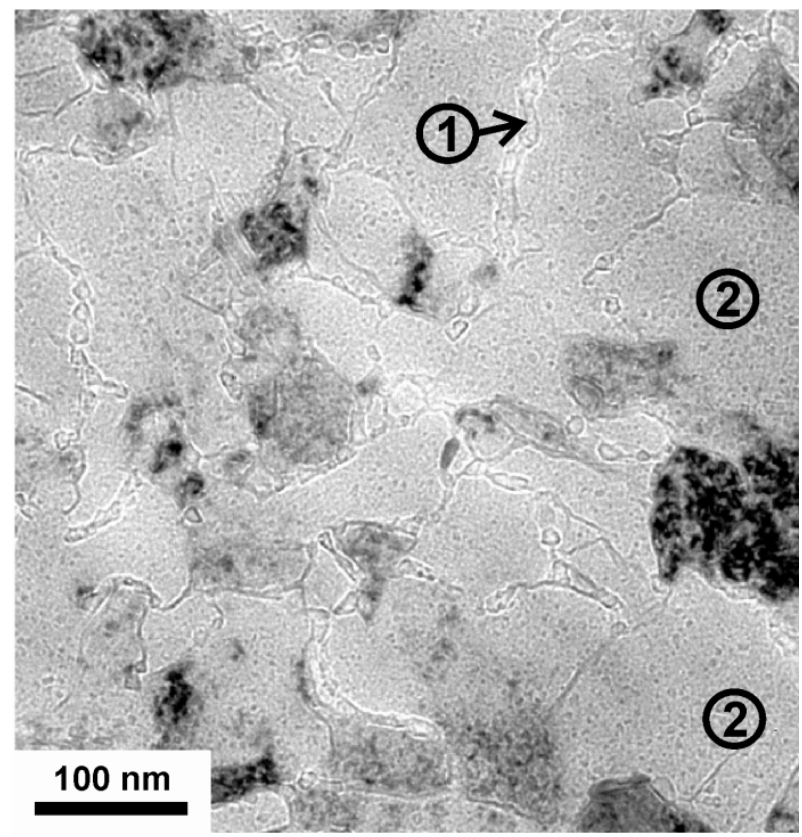

Generally, spinodal decomposition of the cubic solid-solution $\mathrm{Ti}_{1-\mathrm{x}} \mathrm{Al}_{\mathrm{x}} \mathrm{N}$ can be expected at temperatures above $850{ }^{\circ} \mathrm{C}[9,11,20,22]$ which allow for the required kinetic conditions. The spinodal decomposition is a spontaneous process where a cluster or concentration fluctuation amplifies to the equilibrium concentration through diffusion up the concentration gradient [36], when the kinetic requirements allow for it. Therefore, spinodal decomposition will take place within the domains or grains of a solid-solution. In recent years, the effect of grain boundaries and inner surface on spinodal decomposition was investigated and it was found that these surfaces can also stimulate the appearance of concentration waves. Such surface-initiated or directed spinodal decomposition leads to domains repeating the grain boundary geometry $[34,35,37]$.

With the above described changes in structure and morphology the detected features during DSC (Figure 1a) can be interpreted. Starting from temperatures slightly above the deposition temperature, recovery processes are responsible for the detected DSC signal, where also the formation of $\mathrm{w}$-AIN for $\mathrm{T}_{\mathrm{a}} \geq 700{ }^{\circ} \mathrm{C}$ and cubic Ti- and Al-rich domains contribute. The pronounced exothermic feature between 910 and $1300{ }^{\circ} \mathrm{C}$ includes ongoing spinodal decomposition and formation of w-AlN. For $\mathrm{T}_{\mathrm{a}} \geq 1150{ }^{\circ} \mathrm{C}$, the $\mathrm{Ti}_{0.45} \mathrm{Al}_{0.55} \mathrm{~N}$ thin film is largely decomposed into the stable constituents c-TiN and w-AlN. With increasing temperature $\mathrm{T}_{\mathrm{a}}$ the fraction of c-AlN decreases. For $\mathrm{T}_{\mathrm{a}} \geq 1350{ }^{\circ} \mathrm{C}$, recrystallization and coarsening are responsible for the detected DSC features. These exothermal 
processes may be superimposed by endothermic contributions resulting from nitrogen release observed for $\mathrm{T}_{\mathrm{a}} \geq 1140{ }^{\circ} \mathrm{C}$ (Figure $1 \mathrm{~b}$ and $\mathrm{c}$ ).

In general, the decomposition process found for the herein investigated $\mathrm{Ti}_{0.45} \mathrm{Al}_{0.55} \mathrm{~N}$ differs by the early formation of the wurtzite phase from the decomposition route described in $[9,11]$ for single phase cubic $\mathrm{Ti}_{1-\mathrm{x}} \mathrm{Al}_{\mathrm{x}} \mathrm{N}$. The decomposition reactions, especially the transformation of c-AlN to stable $\mathrm{w}-\mathrm{AlN}$, occurs at lower temperatures. Nevertheless, the overall energy input for the decomposition, i.e., the integrated area under the entire DSC curve, is $35.3 \mathrm{~kJ} \mathrm{~mol}^{-1}$ comparable to the $36.2 \mathrm{~kJ} \mathrm{~mol}^{-1}$ reported in [16] for the decomposition of $\mathrm{Ti}_{0.5} \mathrm{Al}_{0.5} \mathrm{~N}$.

\subsubsection{Single phase cubic $\mathrm{Ti}_{0.46} \mathrm{Al}_{0.52} \mathrm{Y}_{0.02} \mathrm{~N}$}

The XRD patterns of powdered 2 mol \% YN containing $\mathrm{Ti}_{1-\mathrm{x}} \mathrm{Al}_{\mathrm{X}} \mathrm{N}$ (removed from their low alloy steel substrates) in their as deposited state and after annealing at $T_{a}$ are presented in Figure 5. These films are prepared by reactive pulsed DC magnetron sputtering using a $\operatorname{Ti}_{0.49} \mathrm{Al}_{0.49} \mathrm{Y}_{0.02}$ target, see experimental section, and exhibit a cubic stabilized structure with a chemical composition of c- $\mathrm{Ti}_{0.46} \mathrm{Al}_{0.52} \mathrm{Y}_{0.02} \mathrm{~N}$ [27]. The strong (200) reflex as well as the smaller (111) reflex for a cubic phase indicate solid-solution.

Figure 5. XRD evolution of single-phase c- $\mathrm{Ti}_{0.46} \mathrm{Al}_{0.52} \mathrm{Y}_{0.02} \mathrm{~N}$ with annealing temperature $\mathrm{T}_{\mathrm{a}}$ up to $1500^{\circ} \mathrm{C}$.



Upon annealing to 700,900 , and $1000{ }^{\circ} \mathrm{C}$, decreasing intensities of these cubic solid-solution matrix-reflexes are observed. The shoulder-formation on both sides of these reflexes, characteristic for cubic Al- and Ti-rich domains (as these would have smaller and larger lattice parameters, respectively) can already be detected for $\mathrm{T}_{\mathrm{a}}=700{ }^{\circ} \mathrm{C}$, i.e., $\sim 200{ }^{\circ} \mathrm{C}$ earlier than for the $\mathrm{c}-\mathrm{Ti}_{0.45} \mathrm{Al}_{0.55} \mathrm{~N}$ film, compare Figure 2. The XRD pattern of $\mathrm{c}-\mathrm{Ti}_{0.46} \mathrm{Al}_{0.52} \mathrm{Y}_{0.02} \mathrm{~N}$ annealed at $1150{ }^{\circ} \mathrm{C}$ still exhibits the presence of cubic solid-solution matrix, along with c-TiN, small fractions of c-AlN, and w-AlN. The formation of $\mathrm{c}-\mathrm{YN}$ precipitates is suggested by a small XRD response at $\sim 31.6 \mathrm{deg}$. The observed retarded decomposition of the $\mathrm{c}-\mathrm{Ti}_{0.46} \mathrm{Al}_{0.52} \mathrm{Y}_{0.02} \mathrm{~N}$ solid-solution as compared to $\mathrm{c}-\mathrm{Ti}_{0.45} \mathrm{Al}_{0.55} \mathrm{~N}$, where at 
$1150{ }^{\circ} \mathrm{C}$ the $\mathrm{XRD}$ peaks are already close to the positions of the stable constituents, is attributed to $\mathrm{Y}$ induced effects as observed also for Cr-Al-Y-N [18,38]. After annealing at $\mathrm{T}_{\mathrm{a}}=1350{ }^{\circ} \mathrm{C}$, the XRD pattern indicates only reflexes that can be assigned to the stable phases c-TiN, c-YN, and w-AlN, with only minor indications for c-AIN (Figure 5). When the film is further annealed to $1500{ }^{\circ} \mathrm{C}$, only pronounced high intensity XRD peaks can be detected with $2 \theta$-values corresponding to c-TiN, c-YN, and $\mathrm{w}-\mathrm{AlN}$ indicating recrystallization and coarsening of the decomposed material.

The morphological evolution with annealing temperature of this $\mathrm{c}-\mathrm{Ti}_{0.46} \mathrm{Al}_{0.52} \mathrm{Y}_{0.02} \mathrm{~N}$ coating is investigated by plan view TEM, see Figure 6 .

Figure 6. Plan view TEM micrographs of the single-phase c- $\mathrm{Ti}_{0.46} \mathrm{Al}_{0.52} \mathrm{Y}_{0.02} \mathrm{~N}$ taken in (a) bright-field low magnification, (b) HRTEM and (c) HAADF STEM mode. The crystallite areas are highlighted by the dashed-line in the HRTEM image. (d) SAED pattern showing only cubic solid-solution $\mathrm{Ti}_{1-\mathrm{x}} \mathrm{Al}_{\mathrm{x}} \mathrm{N}$ reflexes.
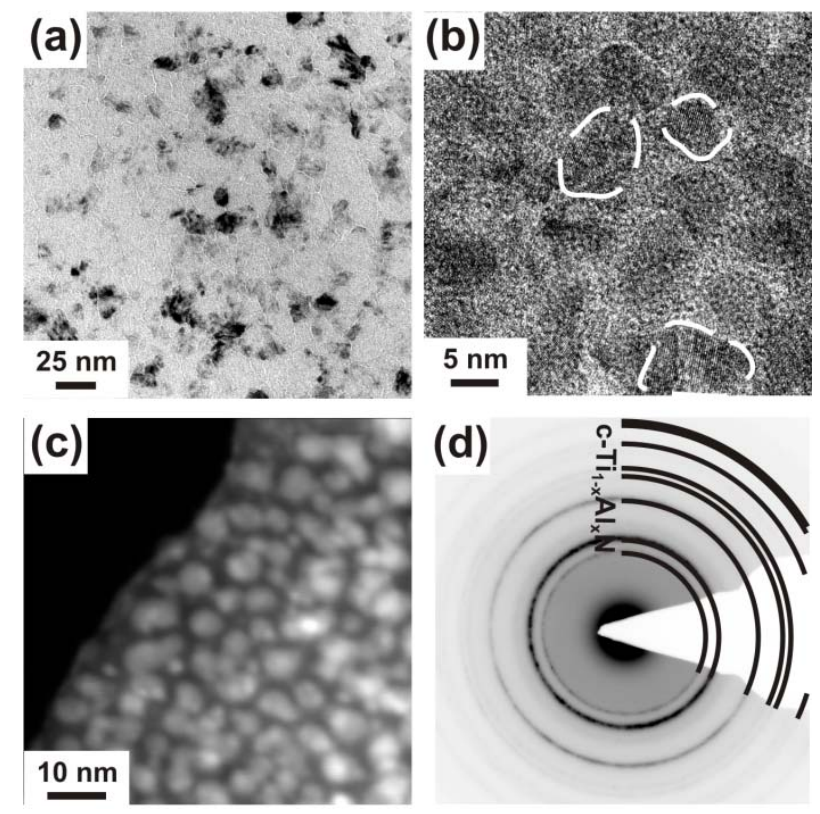

In the as deposited state the coating exhibits a fine-grained microstructure with domain sizes of $<10 \mathrm{~nm}$, much smaller as compared to the $\sim 100 \mathrm{~nm}$ of the $\mathrm{Y}$-free $\mathrm{c}-\mathrm{Ti}_{0.45} \mathrm{Al}_{0.55} \mathrm{~N}$ film (compare Figures 3 and 6). The grain boundaries of the $c-\mathrm{Ti}_{0.46} \mathrm{Al}_{0.52} \mathrm{Y}_{0.02} \mathrm{~N}$ coating are more pronounced, as a bright-contrast tissue-phase can be identified in the bright-field image (Figure 6a). In the HAADF image the tissue phase appears dark (Figure 6c), indicating a lower average atomic number compared to the grains. The HRTEM and HAADF images (Figure $6 \mathrm{~b}$ and c, respectively), exhibit 5-10 nm sized grains (cross-section of the coating-columns, highlighted by the dashed line) encapsulated by the grain boundary phase with thicknesses up to a few nm. Lattice fringes can only be detected within the grains. The SAED pattern (Figure 6d), taken over an area covering several grains as well as the tissue phase, shows only diffraction-rings for a cubic solid-solution with a lattice parameter of $\sim 4.178 \AA$, comparable to that obtained by XRD. Based on these investigations, we assume that the grainboundary phase has a low short-range order structure resulting in an electron (SAED) and X-ray (XRD) amorphous response. 
When performing electron energy-loss spectroscopy (EELS) and EDX in the TEM on the samples, an increased Al content can be detected within the grain-boundary phase with respect to the encapsulated grains. The contents for Ti and Y are evenly distributed within the investigated areas of the as deposited films. As the chemical composition of this film is close to the border line between cubic and wurtzite phase-fields, see [26,27], depending on the deposition conditions and the resulting kinetics (which influence the phase-field ranges), either the cubic or the wurtzite phase can be favored, or both phases could co-exist. Such processes are fundamentally described in [39,40], and competitivegrowth resulting structures are reported in literature for a large variety of different coating systems, ranging from metallic films to nanocomposites, e.g., based on transition metal nitrides or borides [41-44].

Corresponding to the results obtained for $\mathrm{c}-\mathrm{Ti}_{0.45} \mathrm{Al}_{0.55} \mathrm{~N}$, also the $\mathrm{c}-\mathrm{Ti}_{0.46} \mathrm{Al}_{0.52} \mathrm{Y}_{0.02} \mathrm{~N}$ film reveals a decreasing grain size with increasing $\mathrm{T}_{\mathrm{a}}$ to $900{ }^{\circ} \mathrm{C}$ (compare Figures $6 \mathrm{a}$ and $7 \mathrm{a}$ ). The corresponding SAED pattern, Figure $7 \mathrm{~b}$, suggests cubic as well as wurtzite phase contributions.

Figure 7. TEM plan view micrograph of the single-phase $c-T_{0.46} \mathrm{Al}_{0.52} \mathrm{Y}_{0.02} \mathrm{~N}$ after annealing to (a) $900{ }^{\circ} \mathrm{C}$, (c) $1050{ }^{\circ} \mathrm{C}$, and (d) $1350{ }^{\circ} \mathrm{C}$. (b) SAED pattern for the $900{ }^{\circ} \mathrm{C}$ annealed sample.
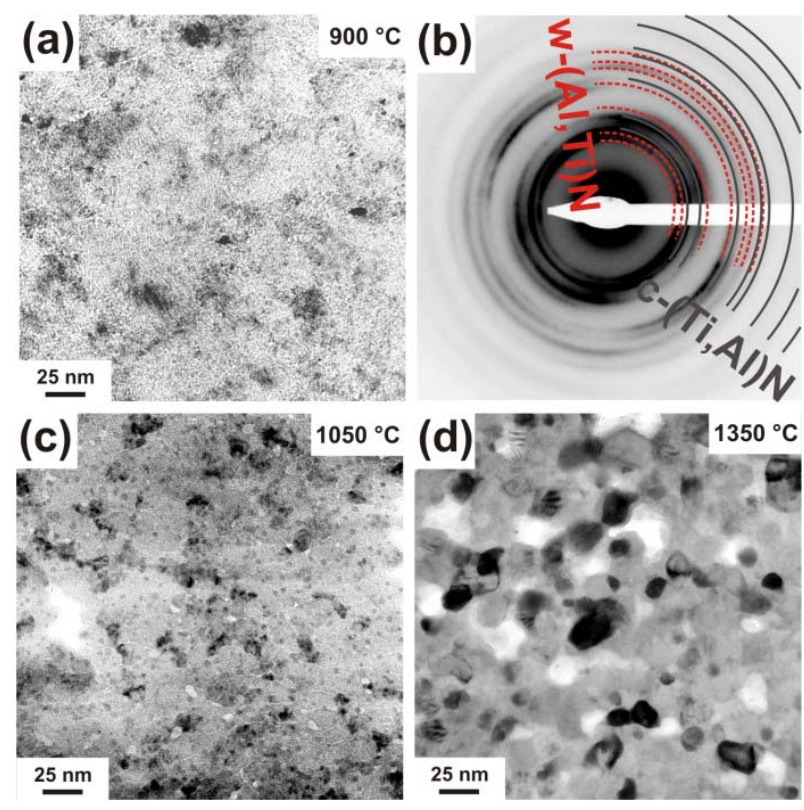

After annealing to $1050{ }^{\circ} \mathrm{C}$, Figure $7 \mathrm{c}$, the coating exhibits $\sim 20 \mathrm{~nm}$ sized domains, surrounded by a bright-contrast phase with diameters between 4.5 and $12 \mathrm{~nm}$. These bright areas could be identified as holes. As for these sample areas, the SAED pattern (not shown here) indicate a decreased wurtzite phase content (as compared to the lower annealing temperatures) the holes might be related to former w-AlN areas. As the formation of wurtzite $\mathrm{AlN}$ from the cubic $\mathrm{Ti}_{1-\mathrm{x}} \mathrm{Al}_{\mathrm{X}} \mathrm{N}$ phase is connected to a huge volume increase (w-AlN has a $\sim 26 \%$ higher specific volume as its metastable cubic counterpart [6]) these areas might break during the TEM sample preparation.

Within the domains, small $\sim 3.5 \mathrm{~nm}$ sized precipitations can be identified, similar to the $1050{ }^{\circ} \mathrm{C}$ annealed $\mathrm{Y}$-free $\mathrm{c}-\mathrm{Ti}_{0.45} \mathrm{Al}_{0.55} \mathrm{~N}$ film. Whereas the latter exhibits an interconnected network of $>100 \mathrm{~nm}$ 
sized grains after annealing at $1350{ }^{\circ} \mathrm{C}$ (see Figure 3), the microstructure of the $\mathrm{c}-\mathrm{Ti}_{0.46} \mathrm{Al}_{0.52} \mathrm{Y}_{0.02} \mathrm{~N}$ film annealed at the same temperature is composed of only $\sim 25 \mathrm{~nm}$ globular grains (Figure 7d). This grain refinement effect can be attributed to $\mathrm{Y}$-induced effects and the additional precipitation of c-YN.

Based on these TEM and XRD investigations, the DSC measurements of the $c-\mathrm{Ti}_{0.46} \mathrm{Al}_{0.52} \mathrm{Y}_{0.02} \mathrm{~N}$ sample, shown in Figure 1a, can be interpreted with respect to the findings for the $\mathrm{Y}$-free c- $\mathrm{Ti}_{0.45} \mathrm{Al}_{0.55} \mathrm{~N}$ sample. Similar to the Y-free film, the first exothermic DSC feature starting at $\sim 500{ }^{\circ} \mathrm{C}$ includes recovery processes, spinodal decomposition, as well as formation of w-AlN. Our results suggest that the smaller grain size and the high-Al containing boundary phase with a lower density promote the formation of w-AlN. Cubic AlN can already be detected after annealing at $\sim 700^{\circ} \mathrm{C}$, hence at lower temperatures as for the Y-free film, compare Figures 2 and 5. In contrast to these results, the development of the $\mathrm{w}$-AIN phase is retarded to higher temperatures. This is also represented in the DSC curve with an increase in peak temperature from $1052{ }^{\circ} \mathrm{C}$ for $\mathrm{c}-\mathrm{Ti}_{0.45} \mathrm{Al}_{0.55} \mathrm{~N}$ to $1118{ }^{\circ} \mathrm{C}$ for c- $\mathrm{Ti}_{0.46} \mathrm{Al}_{0.52} \mathrm{Y}_{0.02} \mathrm{~N}$ (see Figure 1a). Consequently, the onset of mass loss is also shifted by $60{ }^{\circ} \mathrm{C}$ from $1140{ }^{\circ} \mathrm{C}$ for $\mathrm{c}-\mathrm{Ti}_{0.45} \mathrm{Al}_{0.55} \mathrm{~N}$ to $\sim 1200{ }^{\circ} \mathrm{C}$ for $\mathrm{c}-\mathrm{Ti}_{0.46} \mathrm{Al}_{0.52} \mathrm{Y}_{0.02} \mathrm{~N}$ (Figure 1b). Yttrium retards the decomposition of the solid-solution as well as the transformation of c-AlN to w-AlN. The early onset of the formation of $\mathrm{w}-\mathrm{AlN}$ is related to its development from the grain boundary phase. It is envisioned that a further optimization of the deposition conditions, where the amount of the grain boundary phase can be reduced and the cubic phase can further be stabilized, will result in a retarded formation of wAlN, corresponding to the results obtained for Cr-Al-Y-N [18].

\subsubsection{Binary phase cubic/wurtzite $\mathrm{Ti}_{0.41} \mathrm{Al}_{0.57} \mathrm{Y}_{0.02} \mathrm{~N}$}

The XRD pattern of the as deposited 2 mol \% YN containing film, prepared by reactive magnetron DC sputtering of a $\mathrm{Ti}_{0.49} \mathrm{Al}_{0.49} \mathrm{Y}_{0.02}$ target, suggests a binary phase structure composed of cubic and wurtzite (hatched area) solid-solution $\mathrm{Ti}_{1-\mathrm{x}-\mathrm{y}} \mathrm{Al}_{\mathrm{x}} \mathrm{Y}_{\mathrm{y}} \mathrm{N}$ phases, see Figure 8. While the wurtzite phase fraction results in a relatively low-intensity reflection ( $2 \theta$ range between 32 and $37 \mathrm{deg}$ ) in the as deposited state, this intensity increases with increasing $\mathrm{T}_{\mathrm{a}}$ to $1150{ }^{\circ} \mathrm{C}$.

Corresponding to the cubic stabilized $\mathrm{c}-\mathrm{Ti}_{0.46} \mathrm{Al}_{0.52} \mathrm{Y}_{0.02} \mathrm{~N}$ coating, also this binary $\mathrm{c} / \mathrm{w}$ $\mathrm{Ti}_{0.41} \mathrm{Al}_{0.57} \mathrm{Y}_{0.02} \mathrm{~N}$ coating exhibits increasing c-AlN reflexes $(2 \theta \sim 44.7 \mathrm{deg})$ upon annealing to $700{ }^{\circ} \mathrm{C}$, suggesting the onset of spinodal decomposition at relatively low temperatures. Annealing the coating to 1000 and $1150{ }^{\circ} \mathrm{C}$, causes an increasing intensity for the XRD reflexes attributed to the wurtzite solid-solution at $2 \theta \sim 34 \mathrm{deg}$ as well as the c-AlN at $2 \theta \sim 44.7 \mathrm{deg}$. The c- $\mathrm{Ti}_{1-\mathrm{x}-\mathrm{y}} \mathrm{Al}_{\mathrm{x}} \mathrm{Y}_{\mathrm{y}} \mathrm{N}$ peaks shift to lower diffraction angles, suggesting an increase in lattice constant and hence a depletion in AlN or enrichment in TiN of the cubic solid-solution. After annealing to $1350{ }^{\circ} \mathrm{C}$ the coating is mainly composed of phases with lattice constants close to their standard values, hence the XRD peaks match the $2 \theta$ positions for c-TiN and w-AlN, see Figure 8 . Nevertheless, the broad reflexes still suggest small grain sizes, similar to the results obtained for $\mathrm{c}-\mathrm{Ti}_{0.46} \mathrm{Al}_{0.52} \mathrm{Y}_{0.02} \mathrm{~N}$, and indicate retarded decomposition and transformation as compared to the $\mathrm{Y}$-free $\mathrm{c}-\mathrm{Ti}_{0.45} \mathrm{Al}_{0.55} \mathrm{~N}$ film. With increasing the temperature to $1500{ }^{\circ} \mathrm{C}$, the individual grains grow (increased sharpness of the respective XRD reflexes), and also cYN can clearly be detected ( $2 \theta \sim 31.5$ and $52.5 \mathrm{deg})$.

Plan view TEM investigations of this binary phased $\mathrm{c} / \mathrm{w}-\mathrm{Ti}_{0.41} \mathrm{Al}_{0.57} \mathrm{Y}_{0.02} \mathrm{~N}$ coating exhibit a fine grained morphology in the as deposited state, see Figure 9a. 
Figure 8. XRD evolution of binary $\mathrm{c} / \mathrm{w}-\mathrm{Ti}_{0.41} \mathrm{Al}_{0.57} \mathrm{Y}_{0.02} \mathrm{~N}$ with annealing temperature $\mathrm{T}_{\mathrm{a}}$ up to $1500{ }^{\circ} \mathrm{C}$.



Figure 9. Plan view TEM micrographs of binary $\mathrm{c} / \mathrm{w}-\mathrm{Ti}_{0.41} \mathrm{Al}_{0.57} \mathrm{Y}_{0.02} \mathrm{~N}$ in the (a) as deposited state, and after annealing to (b) $900^{\circ} \mathrm{C}$, (c) $1050{ }^{\circ} \mathrm{C}$, and (d) $1350{ }^{\circ} \mathrm{C}$. The small insets in (a) and (b) are the corresponding SAED patterns.
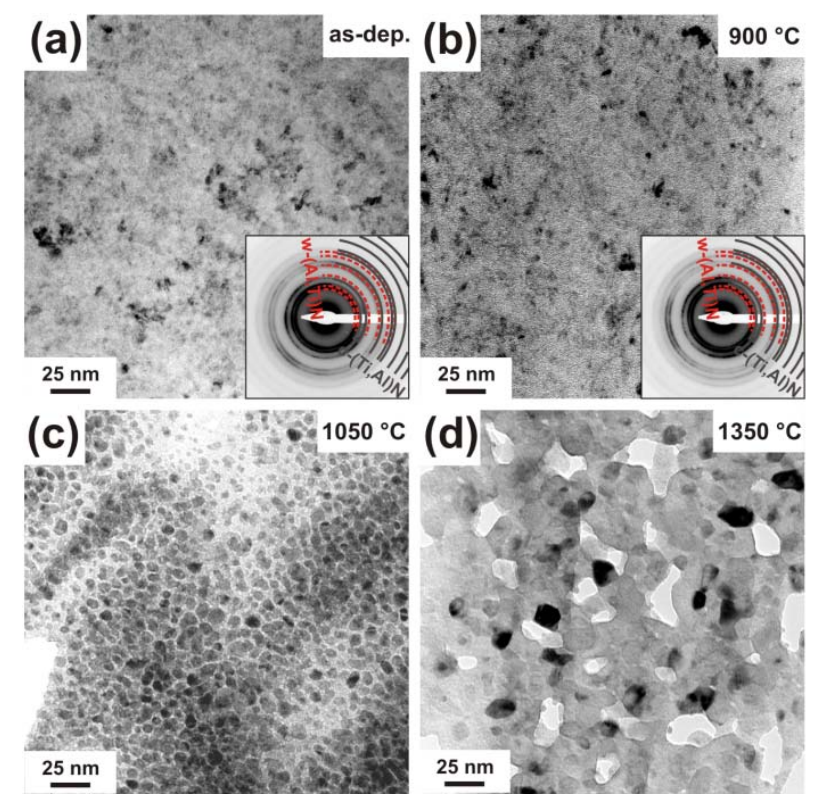

In [27] we investigated this film by cross-sectional TEM and found a tilted columnar microstructure with column diameters at the coating surface below $40 \mathrm{~nm}$ in the as deposited state. The plan view investigations, here, suggest a grain size below $20 \mathrm{~nm}$. The SAED pattern of the as deposited film (inset in Figure 9a) clearly shows the co-existence of cubic and wurtzite phases. After annealing to $900{ }^{\circ} \mathrm{C}$, the TEM plan view micrographs as well as the corresponding SAED pattern show no major 
changes as compared to the as deposited condition (Figure $9 \mathrm{~b}$ ). After annealing to $1050{ }^{\circ} \mathrm{C}$, the coating consists of grains with diameters in the range $5-15 \mathrm{~nm}$, surrounded by a bright-contrast tissue phase, see Figure 9c. Annealing the coating further to $1350{ }^{\circ} \mathrm{C}$ results in the formation of a coarsened (but still small sized), globular grained microstructure, see Figure 9d.

Corresponding to the findings for the $\mathrm{c}-\mathrm{Ti}_{0.45} \mathrm{Al}_{0.55} \mathrm{~N}$ and the $\mathrm{c}-\mathrm{Ti}_{0.46} \mathrm{Al}_{0.52} \mathrm{Y}_{0.02} \mathrm{~N}$ coating also for this binary phased $\mathrm{c} / \mathrm{w}-\mathrm{Ti}_{0.41} \mathrm{Al}_{0.57} \mathrm{Y}_{0.02} \mathrm{~N}$ coating relaxation and recovery effects are responsible for the DSC features between $\sim 430{ }^{\circ} \mathrm{C}$ and the onset temperature of the large exothermic peak at $\sim 920{ }^{\circ} \mathrm{C}$. The latter covers the processes of decomposition, recrystallization and grain growth. In total the energy released of this $\mathrm{c} / \mathrm{w}-\mathrm{Ti}_{0.41} \mathrm{Al}_{0.57} \mathrm{Y}_{0.02} \mathrm{~N}$ coating during annealing to $1500{ }^{\circ} \mathrm{C}$ is $\sim 19.22 \mathrm{~kJ} \mathrm{~mol}^{-1}$.

\subsubsection{Single phase wurtzite $\mathrm{Ti}_{0.38} \mathrm{Al}_{0.54} \mathrm{Y}_{0.08} \mathrm{~N}$}

The XRD pattern of the as deposited $8 \mathrm{~mol} \% \mathrm{YN}$ containing $\mathrm{Ti}_{0.38} \mathrm{Al}_{0.54} \mathrm{Y}_{0.08} \mathrm{~N}$ film exhibits a solidsolution wurtzite structure with lattice parameters of $\mathrm{a} \sim 3.205 \AA$ and $\mathrm{c} \sim 5.220 \AA$ [26], see Figure 10. With increasing temperature to $1000{ }^{\circ} \mathrm{C}$, the XRD patterns suggest only minor changes in structure. The increased XRD reflex intensities indicate only an increased crystallinity. When the coatings are annealed to $1150{ }^{\circ} \mathrm{C}$, new phases can be detected which can be assigned to c-TiN ( $2 \theta \sim 43 \mathrm{deg}$ ). Hence, the solid-solution wurtzite structure decomposes to form TiN precipitates.

Figure 10. XRD evolution of single-phase w- $\mathrm{Ti}_{0.38} \mathrm{Al}_{0.54} \mathrm{Y}_{0.08} \mathrm{~N}$ with annealing temperature $\mathrm{T}_{\mathrm{a}}$ up to $1500^{\circ} \mathrm{C}$.

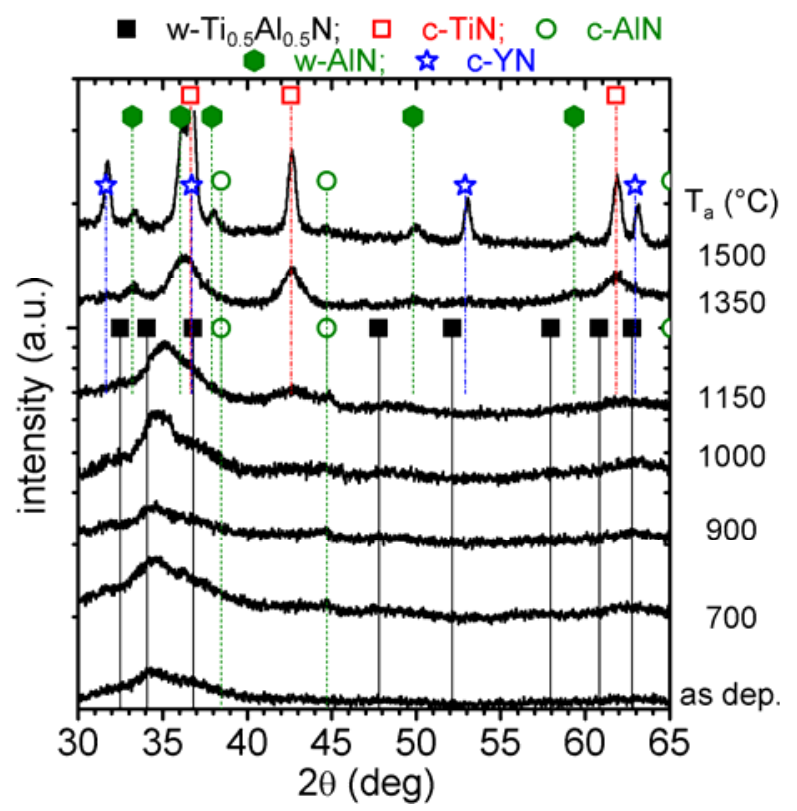

After annealing to $1350{ }^{\circ} \mathrm{C}$, the XRD reflexes can be attributed to the stable phases c-TiN, w-AlN, and c-YN, although the reflexes are still broad. Hence, the grain size is still small, even after annealing to $1350{ }^{\circ} \mathrm{C}$. With a further increase in $\mathrm{T}_{\mathrm{a}}$ to $1500{ }^{\circ} \mathrm{C}$, the XRD peaks are clearly separated and suggest further recrystallization and grain growth. Here, also the c-YN reflexes can clearly be identified.

The plan view TEM investigations of the as deposited $w-\mathrm{Ti}_{0.38} \mathrm{Al}_{0.54} \mathrm{Y}_{0.08} \mathrm{~N}$ coating exhibit a very small grain size, see Figure 11a, as suggested by XRD. The corresponding SAED pattern indicates 
mainly diffraction rings due to a wurtzite phase and almost no indication for a cubic phase (inset in Figure 11a). The TEM plan view as well as the corresponding SAED investigations exhibit no major changes due to an annealing treatment to $900{ }^{\circ} \mathrm{C}$ (see Figure 11b), as compared to the as deposited film. This again is in agreement with the XRD results. Annealing the film to $1050{ }^{\circ} \mathrm{C}$ causes the formation of a clear crystalline grain structure with grain sizes around 3-5 nm, see Figure $11 \mathrm{c}$. Based on the XRD results, this is attributed to the decomposition of the wurtzite phase solid-solution and the precipitation of c-TiN. These grains coarsen during further annealing (Figure 11d).

The small changes in XRD and TEM response between the as deposited and up to $1000{ }^{\circ} \mathrm{C}$ annealed $\mathrm{w}-\mathrm{Ti}_{0.38} \mathrm{Al}_{0.54} \mathrm{Y}_{0.08} \mathrm{~N}$ samples are in agreement with the small DSC feature between 400 and $1000{ }^{\circ} \mathrm{C}$. The peak temperature with $\sim 1200{ }^{\circ} \mathrm{C}$ for this coating is the highest compared to the films probed here, as already identified by XRD and TEM investigations. Also, the onset temperature for mass loss is with $1210{ }^{\circ} \mathrm{C}$ highest for this high $\mathrm{Y}$-containing film. The overall energy released during DSC is $\sim 19.15 \mathrm{~kJ} \mathrm{~mol}^{-1}$ and comparable to that of the $\mathrm{c} / \mathrm{w}-\mathrm{Ti}_{0.41} \mathrm{Al}_{0.57} \mathrm{Y}_{0.02} \mathrm{~N}$ with $19.22 \mathrm{~kJ} \mathrm{~mol}^{-1}$ and c- $\mathrm{Ti}_{0.46} \mathrm{Al}_{0.52} \mathrm{Y}_{0.02} \mathrm{~N}$ with $20.49 \mathrm{~kJ} \mathrm{~mol}^{-1}$.

Figure 11. Plan view TEM micrographs of $\mathrm{w}-\mathrm{Ti}_{0.38} \mathrm{Al}_{0.54} \mathrm{Y}_{0.08} \mathrm{~N}$ in the (a) as deposited state and after annealing at (b) $900{ }^{\circ} \mathrm{C}$, (c) $1050{ }^{\circ} \mathrm{C}$, and (d) $1350{ }^{\circ} \mathrm{C}$. The small insets in (a) and (b) are the corresponding SAED patterns.



\subsection{Hardness development}

The hardness evolution of the $\mathrm{c}-\mathrm{Ti}_{0.45} \mathrm{Al}_{0.55} \mathrm{~N}$, c- $-\mathrm{Ti}_{0.46} \mathrm{Al}_{0.52} \mathrm{Y}_{0.02} \mathrm{~N}, \mathrm{c} / \mathrm{W}-\mathrm{Ti}_{0.41} \mathrm{Al}_{0.57} \mathrm{Y}_{0.02} \mathrm{~N}$, and $\mathrm{W}-\mathrm{Ti}_{0.38} \mathrm{Al}_{0.54} \mathrm{Y}_{0.08} \mathrm{~N}$ coatings with annealing temperatures up to $1200{ }^{\circ} \mathrm{C}$ is presented in Figure 12 . Due to coating flaking no hardness data could be evaluated for higher annealing temperatures. Due to the different microstructures of the various as deposited coatings their hardness varies tremendously. While the single-phase c- $\mathrm{Ti}_{0.45} \mathrm{Al}_{0.55} \mathrm{~N}$ and $\mathrm{c}-\mathrm{Ti}_{0.46} \mathrm{Al}_{0.52} \mathrm{Y}_{0.02} \mathrm{~N}$ films have high hardnesses of $34.6 \pm 2.8$ and $33.4 \pm 2.3 \mathrm{GPa}$, the binary $\mathrm{c} / \mathrm{w}-\mathrm{Ti}_{0.41} \mathrm{Al}_{0.57} \mathrm{Y}_{0.02} \mathrm{~N}$ film has only $23.5 \pm 1.4 \mathrm{GPa}$, and the nearly single phase wurtzite $\mathrm{w}-\mathrm{Ti}_{0.38} \mathrm{Al}_{0.54} \mathrm{Y}_{0.08} \mathrm{~N}$ coating has the lowest hardness with $22.2 \pm 0.4 \mathrm{GPa}$. 
Due to the annealing induced recovery, the hardness of $\mathrm{c}-\mathrm{Ti}_{0.45} \mathrm{Al}_{0.55} \mathrm{~N}$ decreases slightly to $\sim 32 \mathrm{GPa}$ at $500{ }^{\circ} \mathrm{C}$. With a further increase in temperature, the hardness increases due to the ongoing spinodal decomposition and the formation of various obstacles for the dislocation movement. The peak-hardness of $38.5 \pm 3.2 \mathrm{GPa}$ is obtained after annealing to $950{ }^{\circ} \mathrm{C}$, see Figure 12 . At higher temperatures coarsening of the individual domains as well as the ongoing formation of $\mathrm{w}-\mathrm{AlN}$ and recrystallization lead to a decrease in hardness to $19.8 \pm 3.5 \mathrm{GPa}$ at $1200{ }^{\circ} \mathrm{C}$.

The single-phase c- $\mathrm{Ti}_{0.46} \mathrm{Al}_{0.52} \mathrm{Y}_{0.02} \mathrm{~N}$ film has an $\mathrm{H}$ over $\mathrm{T}_{\mathrm{a}}$ curve comparable to the $\mathrm{Y}$-free coating up to temperatures of $\sim 700-850{ }^{\circ} \mathrm{C}$. The smaller grain size as compared to the $\mathrm{c}-\mathrm{Ti}_{0.45} \mathrm{Al}_{0.55} \mathrm{~N}$ coating may explain the less pronounced effect of the spinodal decomposition on the hardness at temperatures above $850{ }^{\circ} \mathrm{C}$. The formation of cubic domains, which takes place within the grains and at grain boundaries, might result in lower coherency strains for small grain-sized samples. Consequently, fewer additional obstacles for dislocation movement are provided. Hence, for this c- $\mathrm{Ti}_{0.46} \mathrm{Al}_{0.52} \mathrm{Y}_{0.02} \mathrm{~N}$ coating no hardness increase upon annealing above $900{ }^{\circ} \mathrm{C}$ is obtained but a small reduction in $\mathrm{H}$ to $\sim 30 \mathrm{GPa}$ occurs. Nevertheless, the hardness remains almost constant at $\sim 30 \mathrm{GPa}$ for $\mathrm{T}_{\mathrm{a}}$ between 900 and $1050{ }^{\circ} \mathrm{C}$, which is in excellent agreement to the small changes in structure and morphology for annealing temperatures up to $1000{ }^{\circ} \mathrm{C}$. Ongoing decomposition of the cubic solid-solution and formation of w-AlN as well as transformation of c-AlN to w-AlN at $\mathrm{T}_{\mathrm{a}}>1050{ }^{\circ} \mathrm{C}$ results in a hardness decrease. But these coatings exhibit the highest hardness values with $28.9 \pm 1.5 \mathrm{GPa}$ at $1150{ }^{\circ} \mathrm{C}$ and $27.9 \pm 1.5 \mathrm{GPa}$ at $1200{ }^{\circ} \mathrm{C}$ of the coatings investigated.

Figure 12. Hardness evolution with post-deposition annealing in $\mathrm{He}$ atmosphere up to $1200{ }^{\circ} \mathrm{C}$ of $\mathrm{c}-\mathrm{Ti}_{0.45} \mathrm{Al}_{0.55} \mathrm{~N}(0 \mathrm{~mol} \% \mathrm{YN}), \mathrm{c}-\mathrm{Ti}_{0.46} \mathrm{Al}_{0.52} \mathrm{Y}_{0.02} \mathrm{~N}$ (2 mol \% YN), binary $\mathrm{c} / \mathrm{w}-\mathrm{Ti}_{0.41} \mathrm{Al}_{0.57} \mathrm{Y}_{0.02} \mathrm{~N}(2 \mathrm{~mol} \% \mathrm{YN})$, and single-phase w- $\mathrm{Ti}_{0.38} \mathrm{Al}_{0.54} \mathrm{Y}_{0.08} \mathrm{~N}(8 \mathrm{~mol} \% \mathrm{YN})$.

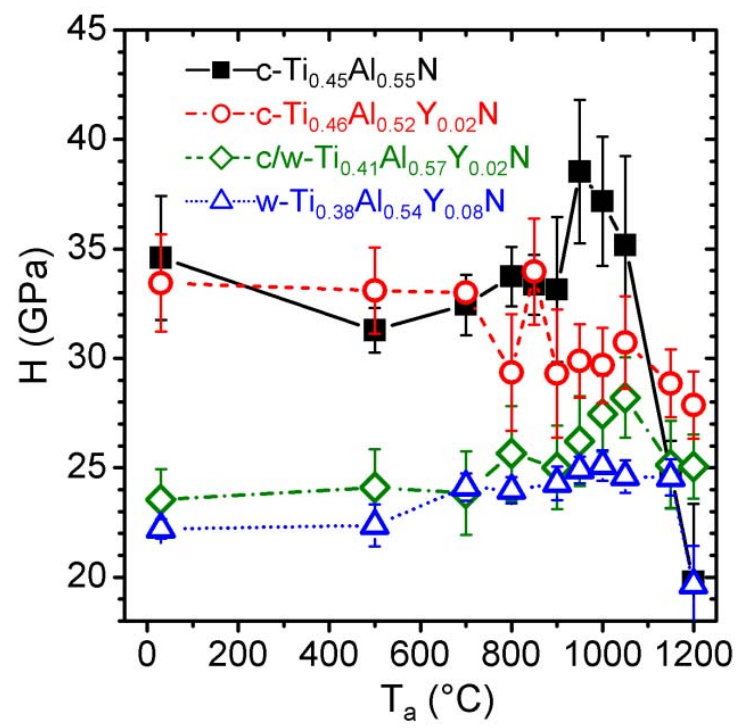

The binary $\mathrm{c} / \mathrm{w}-\mathrm{Ti}_{0.41} \mathrm{Al}_{0.57} \mathrm{Y}_{0.02} \mathrm{~N}$ coating has an almost constant hardness of $24 \mathrm{GPa}$ for temperatures up $700{ }^{\circ} \mathrm{C}$. Crystallization of the Al-rich boundary phases as well as the formation of c-AlN domains result in a slight increase in hardness to $25.0 \pm 1.9 \mathrm{GPa}$ at $900{ }^{\circ} \mathrm{C}$. The decomposition of the wurtzite phase solid-solution to form c-TiN and the formation of a nano-composite lead to a 
further increase in $\mathrm{H}$ to $28.2 \pm 1.8 \mathrm{GPa}$ at $1050{ }^{\circ} \mathrm{C}$. At higher temperatures, the ongoing w-AlN phase formation causes a reduction in $\mathrm{H}$ to $25.1 \pm 1.5 \mathrm{GPa}$ at $1200^{\circ} \mathrm{C}$, which is still a higher hardness than for the as deposited condition with $23.5 \pm 1.4 \mathrm{GPa}$ and also exceeds the hardness of $\mathrm{c}-\mathrm{Ti}_{0.45} \mathrm{Al}_{0.55} \mathrm{~N}$ at $1200{ }^{\circ} \mathrm{C}$.

Due to the pronounced wurtzite phase content for $\mathrm{w}-\mathrm{Ti}_{0.38} \mathrm{Al}_{0.54} \mathrm{Y}_{0.08} \mathrm{~N}$ coatings up to $\mathrm{T}_{\mathrm{a}} \sim 1150{ }^{\circ} \mathrm{C}$, their hardness is the lowest of the coatings investigated. A small increase form $22.3 \pm 0.9 \mathrm{GPa}$ at $500{ }^{\circ} \mathrm{C}$ to $24.6 \pm 0.8 \mathrm{GPa}$ at $1150{ }^{\circ} \mathrm{C}$ can be related to the decomposition of the wurtzite phase solidsolution to form c-TiN and c-YN precipitates, see Figures 11 and 12.

\section{Summary and Conclusions}

Reactive DC magnetron sputtering of powder metallurgically prepared $\mathrm{Ti}_{0.50} \mathrm{Al}_{0.50}, \mathrm{Ti}_{0.49} \mathrm{Al}_{0.49} \mathrm{Y}_{0.02}$, and $\mathrm{Ti}_{0.46} \mathrm{Al}_{0.46} \mathrm{Y}_{0.08}$ targets result in the formation of single-phase $\mathrm{c}-\mathrm{Ti}_{0.45} \mathrm{Al}_{0.55} \mathrm{~N}$, binary $\mathrm{c} / \mathrm{w}-\mathrm{Ti}_{0.41} \mathrm{Al}_{0.57} \mathrm{Y}_{0.02} \mathrm{~N}$ and single-phase $\mathrm{w}-\mathrm{Ti}_{0.38} \mathrm{Al}_{0.54} \mathrm{Y}_{0.08} \mathrm{~N}$ coatings. By applying pulsed $\mathrm{DC}$ to the $\mathrm{Ti}_{0.49} \mathrm{Al}_{0.49} \mathrm{Y}_{0.02}$ target, instead of DC, the coating can be stabilized in its cubic metastable state, as thereby the deposition conditions change and the $\mathrm{Al}$ content of the film decreases to $\mathrm{c}-\mathrm{Ti}_{0.46} \mathrm{Al}_{0.52} \mathrm{Y}_{0.02} \mathrm{~N}$. This allows for detailed investigations of the thermal stability of $\mathrm{Ti}_{1-\mathrm{x}-\mathrm{y}} \mathrm{Al}_{\mathrm{x}} \mathrm{Y}_{\mathrm{y}} \mathrm{N}$ coatings as a function of their $\mathrm{Y}$-content as well as their microstructure and morphology. Differential scanning calorimetry in combination with thermo gravimetric analyses and mass spectroscopy in $\mathrm{He}$ atmosphere reveal increasing thermal stability with increasing $\mathrm{Y}$ content from $\mathrm{y}=0.0$ to 0.08 as the peak temperature of the major exothermic feature increases from 1052 to $1197{ }^{\circ} \mathrm{C}$. XRD in combination with TEM and HRTEM investigations suggest the highest contribution of spinodal decomposition to the overall transformation for the $\mathrm{Y}$-free film $\mathrm{c}-\mathrm{Ti}_{0.45} \mathrm{Al}_{0.55} \mathrm{~N}$, which exhibit also the largest grain size (column diameter) of $\sim 100 \mathrm{~nm}$ in the as deposited state. Consequently, this coating shows the most pronounced hardness increase from $\sim 35$ to $38 \mathrm{GPa}$ when annealed to $950{ }^{\circ} \mathrm{C}$. The cubic stabilized and $\mathrm{Y}$-alloyed coating $\mathrm{c}-\mathrm{Ti}_{0.46} \mathrm{Al}_{0.52} \mathrm{Y}_{0.02} \mathrm{~N}$ has an as deposited grain size of $\sim 10 \mathrm{~nm}$ and hardness of $33 \mathrm{GPa}$. HRTEM, EDS and EELS suggest that the few nm thin grain boundary phase has a comparable $\mathrm{Ti}$ and $\mathrm{Y}$ content, but higher $\mathrm{Al}$ content as the encapsulated grains. These areas promote the formation of AlN upon annealing to higher temperatures. Consequently, cubic as well as wurtzite phase AlN can be observed already after annealing at $700{ }^{\circ} \mathrm{C}$. Nevertheless, the overall decomposition of the metastable cubic solid-solution $\mathrm{Ti}_{1-\mathrm{x}-\mathrm{y}} \mathrm{Al}_{\mathrm{x}} \mathrm{Y}_{\mathrm{y}} \mathrm{N}$ is retarded with respect to the Y-free coating. This $c-\mathrm{Ti}_{0.46} \mathrm{Al}_{0.52} \mathrm{Y}_{0.02} \mathrm{~N}$ coating has the highest hardness at $\mathrm{T}_{\mathrm{a}} \geq 1000{ }^{\circ} \mathrm{C}$ of the coatings investigated with $\sim 29$ and $28 \mathrm{GPa}$ for $\mathrm{T}_{\mathrm{a}}=1150$ and $1200{ }^{\circ} \mathrm{C}$, respectively.

Due to the wurtzite phase fraction of the $\mathrm{c} / \mathrm{w}-\mathrm{Ti}_{0.41} \mathrm{Al}_{0.57} \mathrm{Y}_{0.02} \mathrm{~N}$ and $\mathrm{w}-\mathrm{Ti}_{0.38} \mathrm{Al}_{0.54} \mathrm{Y}_{0.08} \mathrm{~N}$ coatings, their hardness is with $\sim 24$ and $22 \mathrm{GPa}$, the smallest in the as deposited state. But due to the $\mathrm{Y}$-content these coatings exhibit a high thermal stability, where annealing related microstructural changes and the formation of $\mathrm{Al}$ - and Ti-rich domains for $\mathrm{c} / \mathrm{w}-\mathrm{Ti}_{0.41} \mathrm{Al}_{0.57} \mathrm{Y}_{0.02} \mathrm{~N}$ result in an hardness increase to $\sim 28 \mathrm{GPa}$ at $\mathrm{T}_{\mathrm{a}}=1050{ }^{\circ} \mathrm{C}$. Almost no c-AlN formation could be detected during the annealing treatment of the almost single phase $\mathrm{w}-\mathrm{Ti}_{0.38} \mathrm{Al}_{0.54} \mathrm{Y}_{0.08} \mathrm{~N}$ coatings. Consequently, their hardness only increases to $\sim 25 \mathrm{GPa}$ upon annealing to $\mathrm{T}_{\mathrm{a}}$ between 700 and $1150^{\circ} \mathrm{C}$, caused by the precipitation of c-TiN and c-YN. 
Based on our results, we can conclude that $\mathrm{Y}$ effectively retards the decomposition process of supersaturated phases. Furthermore, it is envisioned that an optimization of the deposition conditions, where the amount of the grain boundary phase (which can act as nucleation sites for AlN) can be reduced and the cubic phase can further be stabilized, will result in a retarded formation of w-AlN. Thereby, the hardness reduction due to the promoted formation of w-AlN can be shifted to higher temperatures.

\section{Acknowledgements}

This work is supported by the European Commission through the project INNOVATIAL NMP3CT-2005-515844 and the Austrian Science Fund FWF through the START Project Y371-N14. The authors would like to thank Steffen Schmidt for technical support at the FEI Titan.

\section{References and Notes}

1. North, B. Six issues for the hard coatings community. Surf. Coat. Technol. 1998, 106, 129-134.

2. Münz, W.D. Titanium aluminum nitride films: A new alternative to TiN coatings. J. Vac. Sci. Technol., A 1986, 4, 2717-2725.

3. Mayrhofer, P.H.; Mitterer, C.; Hultman, L.; Clemens, H. Microstructural design of hard coatings. Prog. Mater Sci. 2006, 51, 1032-1114.

4. Fallböhmer, P.; Rodríguez, C.A.; Özel, T.; Altan, T. High-speed machining of cast iron and alloy steels for die and mold manufacturing. J. Mater. Process. Technol. 2000, 98, 104-115.

5. Yamamoto, K.; Kujime, S.; Fox-Rabinovich, G. Effect of alloying element (Si,Y) on properties of AIP deposited (Ti,Cr,Al)N coating. Surf. Coat. Technol. 2008, 203, 579-583.

6. Mayrhofer, P.H.; Music, D.; Schneider, J.M. Influence of the Al distribution on the structure, elastic properties, and phase stability of supersaturated $\mathrm{Ti}_{1-\mathrm{x}} \mathrm{Al}_{\mathrm{x}} \mathrm{N}$. J. Appl. Phys. 2006, 100, $0949061-5$.

7. Holec, D.; Rovere, F.; Mayrhofer, P.H.; Barna, P.B. Pressure-dependent stability of cubic and wurtzite phases within the TiN-AlN and CrN-AlN systems. Scripta Mater. 2010, 62, 349-352.

8. Cremer, R.; Witthaut, M.; Neuschütz, D. Experimental determination of the metastable (Ti,Al)N phase diagram up to $700{ }^{\circ} \mathrm{C}$. In Value-Edition Metallurgy; Cho, W.D., Sohn, H.Y., Eds.; The Minerals \& Metals Society: Warrendale, PA, USA, 1998; pp. 249-258.

9. Hörling, A.; Hultman, L.; Oden, M.; Sjölén, J.; Karlsson, L. Thermal stability of arc evaporated high aluminum-content $\mathrm{Ti}_{1-\mathrm{x}} \mathrm{Al}_{\mathrm{x}} \mathrm{N}$ thin films. J. Vac. Sci. Technol., A 2002, 20, 1815-1823.

10. Kimura, A.; Kawate, M.; Hasegawa, H.; Suzuki, T. Anisotropic lattice expansion and shrinkage of hexagonal TiAlN and CrAlN films. Surf. Coat. Technol. 2003, 169, 367-370.

11. Mayrhofer, P.H.; Hörling, A.; Karlsson, L.; Sjölén, J.; Larsson, T.; Mitterer, C.; Hultman, L. Selforganized nanostructures in the Ti-Al-N system. Appl. Phys. Lett. 2003, 83, 2049-2051.

12. Kutschej, K.; Mayrhofer, P.H.; Kathrein, M.; Polcik, P.; Tessadri, R.; Mitterer, C. Structure, mechanical and tribological properties for sputtered $\mathrm{Ti}_{1-\mathrm{x}} \mathrm{Al}_{\mathrm{x}} \mathrm{N}$ coatings with $0.5 \leq \mathrm{x} \leq 0.75$. Surf. Coat. Technol. 2005, 200, 2358-2365.

13. Mayrhofer, P.H.; Music, D.; Schneider, J.M. Ab initio calculated binodal and spinodal of cubic $\mathrm{Ti}_{1-\mathrm{x}} \mathrm{Al}_{\mathrm{x}} \mathrm{N}$. Appl. Phys. Lett. 2006, 88, 071922:1-071922:3. 
14. Hultman, L. Thermal stability of nitride thin films. Vacuum 2000, 57, 1-30.

15. Mayrhofer, P.H.; Mitterer, C. High-temperature properties of nanocomposite $\operatorname{TiB}_{x} \mathrm{~N}_{\mathrm{y}}$ and $\operatorname{TiB}_{\mathrm{x}} \mathrm{C}_{\mathrm{y}}$ coatings. Surf. Coat. Technol. 2000, 133, 131-137.

16. Mayrhofer, P.H.; Hultman, L.; Schneider, J.M.; Staron, P.; Clemens, H. Spinodal decomposition of cubic $\mathrm{Ti}_{1-\mathrm{x}} \mathrm{Al}_{\mathrm{x}} \mathrm{N}$ : Comparison between experiments and modeling. Int. J. Mater. Res. 2007, 98, 1054-1059.

17. Willmann, H.; Mayrhofer, P.H.; Persson, P.O.A.; Reiter, A.E.; Hultman, L.; Mitterer, C. Thermal stability of Al-Cr-N hard coatings. Scripta Mater. 2006, 54, 1847-1851.

18. Rovere, F.; Mayrhofer, P.H. Thermal stability and thermo-mechanical properties of magnetron sputtered Cr-Al-Y-N coatings. J. Vac. Sci. Technol., A 2008, 26, 29-35.

19. Rachbauer, R.; Massl, S.; Stergar, E.; Moser, M.; Mayrhofer, P.H. Three-dimensional atom probe investigations of Ti-Al-N thin films. Scripta Mater. 2009, 61, 725-728.

20. Adibi, F.; Petrov, I.; Hultman, L.; Wahlstrom, U.; Shimizu, T.; McIntyre, D.; Greene, J.E.; Sundgren, J.E. Defect structure and phase transitions in epitaxial metastable cubic $\mathrm{Ti}_{0.5} \mathrm{Al}_{0.5} \mathrm{~N}$ alloys grown on $\mathrm{MgO}(001)$ by ultra-high-vacuum magnetron sputter deposition. J. Appl. Phys. 1991, 69, 6437-6350.

21. Vepřek, S.; Männling, H.D.; Jilek, M.; Holubar, P. Avoiding the high-temperature decomposition and softening of $\left(\mathrm{Al}_{1-\mathrm{x}} \mathrm{Ti}_{\mathrm{x}}\right) \mathrm{N}$ coatings by the formation of stable superhard nc- $\left(\mathrm{Al}_{1-\mathrm{x}} \mathrm{Ti}_{\mathrm{x}}\right) \mathrm{N} / \mathrm{a}-\mathrm{Si}_{3} \mathrm{~N}_{4}$ nanocomposite. Mater. Sci. Eng., A 2004, 366, 202-205.

22. Zhang, R.F.; Vepřek, S. Metastable phases and spinodal decomposition in $\operatorname{Ti}_{1-x} A_{x} N$ system studied by $a b$ initio and thermodynamic modeling, a comparison with the $\mathrm{TiN}-\mathrm{Si}_{3} \mathrm{~N}_{4}$ system. Mater. Sci. Eng., A 2007, 448, 111-119.

23. PalDey, S.; Deevi, S.C. Single layer and multilayer wear resistant coatings of (Ti,Al)N: a review. Mater. Sci. Eng., A 2003, 342, 58-79.

24. Pint, B.A. Experimental observations in support of the dynamic segregation theory to explain the reactive element effect. Oxid. Met. 1996, 45, 1-37.

25. Donohue, L.A.; Smith, I.J.; Münz, W.D.; Petrov, I.; Greene, J.E. Microstructure and oxidationresistance of $\mathrm{Ti}_{1-\mathrm{x}-\mathrm{y}-\mathrm{z}} \mathrm{Al}_{\mathrm{x}} \mathrm{Cr}_{\mathrm{y}} \mathrm{Y}_{\mathrm{z}} \mathrm{N}$ layers grown by combined steered-arc/unbalanced-magnetronsputter deposition. Surf. Coat. Technol. 1997, 94, 226-231.

26. Moser, M.; Mayrhofer, P.H. Yttrium-induced structural changes in sputtered $\operatorname{Ti}_{1-x} \mathrm{Al}_{\mathrm{X}} \mathrm{N}$ thin films. Scripta Mater. 2007, 57, 357-360.

27. Moser, M.; Mayrhofer, P.H.; Székely, L.; Sáfrán, G.; Barna, P.B. Influence of bipolar pulsed DC magnetron sputtering on elemental composition and micro-structure of $\mathrm{Ti}-\mathrm{Al}-\mathrm{Y}-\mathrm{N}$ thin films. Surf. Coat. Technol. 2008, 203, 148-155.

28. Mayrhofer, P.H.; Mitterer, C. High-temperature properties of nanocomposite $\operatorname{TiB}_{\mathrm{x}} \mathrm{N}_{\mathrm{y}}$ and $\operatorname{TiB}_{\mathrm{x}} \mathrm{C}_{\mathrm{y}}$ coatings. Surf. Coat. Technol. 2000, 133, 131-137.

29. Powder Diffraction File (Card 00-038-1420 TiN; 00-025-1495 c-AlN; 00-025-1133 w-AlN; 00-035-0779 c-YN), International Centre for Diffraction Data, JCPDF-ICDD, 2007.

30. Mayrhofer, P.H.; Kunc, F.; Musil, J.; Mitterer, C. A comparative study on reactive and nonreactive unbalanced magnetron sputter deposition of TiN coatings. Thin Solid Films 2002, 415, $151-159$. 
31. Rovere, F.; Music, D.; Ershov, S.; to Baben, M.; Fuss, H.-G.; Schneider, J.M.; Mayrhofer, P.H. Experimental and computational study on the phase stability of cubic Al containing transition metal nitrides. J. Phys. D: Appl. Phys. 2010, 43, 035302.

32. Mayrhofer, P.H.; Fischer, F.D.; Böhm, H.J.; Mitterer, C.; Schneider, J.M. Energetic balance and kinetics for the decomposition of supersaturated $\mathrm{Ti}_{1-x} \mathrm{Al}_{\mathrm{x}} \mathrm{N}$. Acta Mater. 2007, 55, 1441-1446.

33. Miller, M.K.; Hyde, J.M.; Hetherington, M.G.; Cerezo, A.; Smith, G.D.W.; Elliott, C.M. Spinodal decomposition in $\mathrm{Fe}-\mathrm{Cr}$ alloys: Experimental study at the atomic level and comparison with computer models-I. Introduction and methodology. Acta Metallurg. Mater. 1995, 43, 3385-3401.

34. Puri, S.; Frisch, H.L. Surface-directed spinodal decomposition: Modelling and numerical simulations. J. Phys. Condens. Matter 1997, 9, 2109-21033.

35. Razumov, I.K.; Gornostyrev, Y.N.; Yermakov, A.Y. Kinetics of spinodal decomposition in driven nanocrystalline alloys. J. Alloys Compd. 2007, 434, 535-539.

36. Cahn, J.W. On spinodal decomposition. Acta Metallurg. 1961, 9, 795-801.

37. Ramanarayan, H.; Abinandanan, T.A. Grain boundary effects on spinodal decomposition: II. Discontinuous microstructures. Acta Mater. 2004, 52, 921-930.

38. Rovere, F.; Mayrhofer, P.H.; Reinholdt, A.; Mayer, J.; Schneider, J.M. The effect of yttrium incorporation on the oxidation resistance of Cr-Al-N coatings. Surf. Coat. Technol. 2008, 202, 5870-5875.

39. Holleck, H. Metastable coatings - prediction of composition and structure. Surf. Coat. Technol. 1988, 36, 151-159.

40. Barna, P.B.; Adamik, M. Fundamental structure forming phenomena of polycrystalline films and the structure zone models. Thin Solid Films 1998, 317, 27-33.

41. Barna, P.B. Crystal growth and recrystallization during structure evolution of thin films. In Diagnostics and Applications of Thin Films; Eckertová, L., Ruzicka, T., Eds.; Institute of Physics Publishing: Bristol, UK, 1992; pp. 295-310.

42. Vepřek, S. The search for novel superhard materials. J. Vac. Sci. Technol., A 1999, 17, 2401-2420.

43. Patscheider, J.; Zehnder, T.; Diserens, M. Structure-performance relations in nanocomposite coatings. Surf. Coat. Technol. 2001, 146, 201-208.

44. Mayrhofer, P.H.; Mitterer, C.; Wen, J.G.; Greene, J.E.; Petrov, I. Self-organized nanocolumnar structure in superhard $\mathrm{TiB}_{2}$ thin films. Appl. Phys. Lett. 2005, 86, 131909.

(C) 2010 by the authors; licensee Molecular Diversity Preservation International, Basel, Switzerland. This article is an open-access article distributed under the terms and conditions of the Creative Commons Attribution license (http://creativecommons.org/licenses/by/3.0/). 